\title{
Penerapan Metode K-Nearest Neighbor Untuk Sistem Pendukung Keputusan Identifikasi Penyakit Diabetes Melitus
}

\author{
Umikulsum Indah Lestari*1, Anis Yusrotun Nadhiroh ${ }^{\mathbf{2}}$, Cahyuni Novia ${ }^{\mathbf{3}}$ \\ 1,2,3 Universitas Nurul Jadid; Paiton-Probolinggo, telp/fax : 08883077077 \\ ${ }^{3}$ Jurusan Teknik Informatika, Fakultas Teknik, UNUJA, Probolinggo \\ e-mail: *11 umikulsumindah@gmail.com, ${ }^{2}$ ayusrotun@ gmail.com, ${ }^{3}$ vhie771108@ gmail.com
}

\begin{abstract}
Abstrak
Diabetes melitus merupakan penyakit tidak menular (PTM) yang telah menyebar ke seluruh dunia. Faktor yang dapat menyebabkan seseorang menderita diabetes melitus diantaranya tekanan darah tinggi, obesitas, riwayat penyakit diabetes melitus dalam keluarga, usia, serta pola hidup dan diet tidak sehat. Faktor lain yang menjadi pemicu tingginya tingkat kematian akibat diabetes melitus adalah lambatnya diagnosa karena jumlah tenaga medis yang sedikit terutama di kota kecil. Beberapa uji klinis harus dilakukan untuk mengetahui seseorang terjangkit penyakit diabetes melitus atau tidak, proses uji klinis tersebut memakan waktu yang tidak sebentar. Berdasarkan permasalahan tersebut, maka dibuat sebuah sistem pendukung keputusan untuk identifikasi penyakit diabetes melitus dengan menggunakan metode klasifikasi K-Nearest Neighbor (KNN) dengan 8 variabel yaitu jumlah kehamilan, kadar glukosa, tekanan darah, ketebalan lipatan kulit trisep, insulin, index masa tubuh (IMT), riwayat penyakit diabetes mellitus dalam keluarga, serta usia. Berdasarkan implementasi dan pengujian, dengan nilai $k=23$ didapatkan tingkat akurasi sebesar 0.96 atau 96\%, tingkat akurasi tersebut dinilai cukup tinggi sehingga penelitian ini dinilai telah berhasil menerapkan metode KNN untuk sistem pendukung keputusan identifikasi penyakit diabetes melitus sejak dini.
\end{abstract}

Kata kunci : K-Nearest Neighbor, identifikasi, diabetes melitus.

\begin{abstract}
Diabetes mellitus is a non-communicable disease that has spread throughout the world. Factors that can cause a person to suffer from diabetes mellitus include high blood pressure, obesity, history of diabetes mellitus in the family, age, as well as unhealthy lifestyle and diet. Another factor that triggers the high rate of death due to diabetes mellitus is the delay in diagnosis due to the small number of medical personnel, especially in small towns. Several clinical trials must be carried out to determine whether someone has diabetes mellitus or not; and the clinical trial process takes a long time. Based on these problems, a decision support system was made for the identification of diabetes mellitus using the K-Nearest Neighbor classification method with 8 variables, namely the number of pregnancies, glucose levels, blood pressure, triceps skinfold thickness, insulin, body mass index (BMI), family history of diabetes mellitus, and age. Based on implementation and testing, with a value of $k=23$, an accuracy rate of 0.96 or $96 \%$ is obtained, the accuracy level is considered high enough so that this study is considered to have succeeded in implementing the KNN method for a decision support system for early identification of diabetes mellitus.
\end{abstract}

Keywords: K-Nearest Neighbor, identification, diabetes melitus 


\section{PENDAHULUAN}

Diabetes melitus merupakan penyakit tidak menular (PTM) yang telah menyebar ke seluruh dunia. Diabetes melitus mempengaruhi lebih dari 415 juta orang pada tahun 2015, dan angka tersebut diperkirakan akan meningkat menjadi 642 juta pada tahun 2040 [1]. Diabetes melitus dapat disebabkan oleh berbagai variabel, antara lain tekanan darah tinggi, obesitas, riwayat keluarga yang terkena diabetes melitus, usia, serta gaya hidup dan makanan yang tidak sehat [2]. Gejala awal diabetes melitus memang seringkali tidak terlihat. Oleh sebab itu, banyak orang baru menyadari adanya diabetes melitus ketika telah mengalami komplikasi [3] diabetes melitus yang tidak terkontrol dapat menyebabkan komplikasi jangka panjang, merusak pembulu darah dan saraf serta organ penting didalam tubuh bahkan kematian [4] Faktor lain yang menjadi pemicu tingginya tingkat kematian akibat diabetes mellitus adalah lambatnya diagnosa pada pasien karena terbatasnya jumlah tenaga medis, utamanya kota-kota kecil. Saat ini, telah banyak rumah sakit yang menggunakan database untuk mengumpulkan dan menyimpan data terkait diabetes melitus, namun data yang dikumpulkan belum dapat digunakan secara optimal. Beberapa uji klinis harus dilakukan untuk menentukan apakah seseorang menderita diabetes melitus, proses uji klinis tersebut memakan waktu yang tidak sebentar. [5]

Terdapat beberapa penelitian yang telah dilakukan oleh beberapa peneliti sebelumnya, terkait identifikasi penyakit diabetes melitus. Penelitian yang dilakukan oleh Hadli Fadli Santoso, Eko Darwiyanto, dan Untari Novia Wisesty dengan judul "Analisis dan Implementasi Metode Certainty Factor Pada Sistem Pendukung Pengambilan Keputusan untuk Penyakit Diabetes Melitus". Metode yang dipergunakan dalam penelitian ini ialah metode Certainty Factor. Penelitian ini menghasilkan SPPK diabetes melitus dengan akurasi 80\%, SPPK ini dinilai sangat membantu dalam proses diagnosa diabetes melitus [6]. Penelitian kedua dilakukan oleh Risky Aswi Ramadhani dan Ratih Kumalasari Niswatin dengan judul "Sistem Diagnosa Diabetes Menggunakan Metode K-NN". Data yang dipergunakan pada saat penelitian ini sebanyak 24 data latih dan 7 data uji, mencakup enam variabel: di malam hari sering buang air kecil, luka/goresan sulit sembuh, mudah lelah, gusi berdarah, penurunan cepat dan tiba-tiba dari berat badan, dan keinginan kuat untuk makan dan minum, serta menggunakan nilai $\mathrm{k}=3$. Hasil uji akurasi metode KNN mencapai 85,71\% [7]. Penelitian ketiga dilakukan oleh Noviandi dengan judul "Implementasi Algoritma Decision Tree C4.5 Untuk Prediksi Penyakit Diabetes". Penelitian ini bertujuan untuk membangun model prediksi kemungkinan seseorang terjangkit penyakit diabetes melitus menggunakan algoritma C4.5. Database Pima Indians Diabetes (PPID) digunakan untuk membuat prediksi yang berjumlah 768 data dengan delapan variabel yaitu jumlah kehamilan, kadar glukosa, tekanan darah, ketebalan lipatan kulit trisep, kadar insulin, index masa tubuh (IMT), riwayat diabetes melitus dalam keluarga, serta usia. Akurasi hasil prediksi sebesar $70.32 \%$ [8].

Berdasarkan latar belakang yang telah diuraikan, maka saat ini dibutuhkan sistem pendukung keputusan (SPK) untuk identifikasi penyakit diabetes melitus. (SPK) adalah sistem yang menghubungkan informasi terkomputerisasi dengan pengguna atau pengambil keputusan[9]. Pada penelitian saat ini mengajukan topik yang serupa dengan metode penelitian yang berbeda. Penelitian ini menggunakan suatu teknik dalam data mining yaitu klasifikasi KNearest Neighbor (KNN)dengan 8 variabel yaitu jumlah kehamilan,kadar gula darah (glukosa), tekanan darah, ketebalan lipatan kulit trisep, kadar insulin, index masa tubuh (IMT), riwayat penyakit diabetes melitus dalam keluarga, serta usia. Metode klasifikasi K-Nearest Neighbor (KNN)merupakan salah satu metode yang digunakan untuk mengklasifikasikan objek berdasarkan data latih dengan jarak terdekat[10]. Sistem pendukung keputusan ini diharapkan dapat menghasilkan tingkat akurasi yang jauh lebih tinggi dari penelitian sebelumnya, sehingga

Lestari, et., al [Penerapan Metode K-Nearest Neighbor Untuk Sistem Pendukung Keputusan Identifikasi Penyakit Diabetes Melitus] 
diharapkan dapat mencegah kemungkinan terburuk yang akan terjadi akibat penyakit diabetes melitus.

\section{METODE PENELITIAN}

Model penelitian yang dirancang pada penelitian ini bertujuan untuk memudahkan proses identifikasi penyakit diabetes melitus.

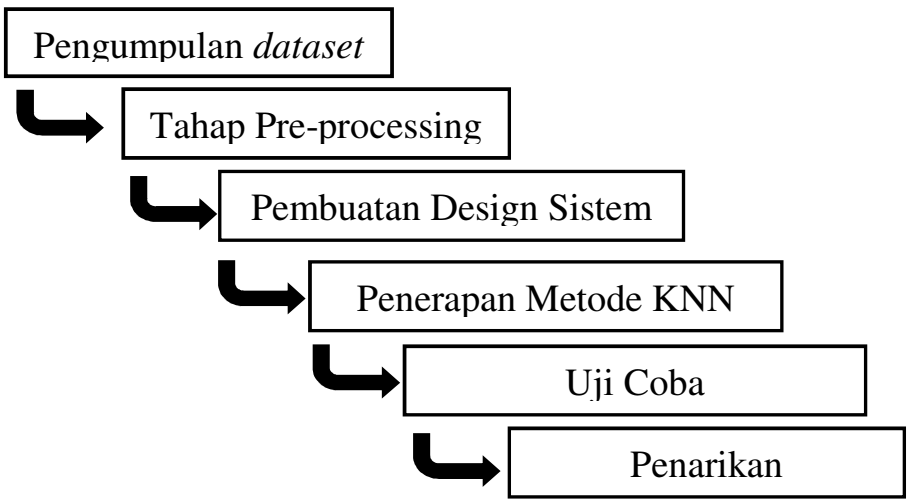

Gambar 1. Rancangan Penelitian

\subsection{Pengumpulan Dataset}

Dataset seputar penyakit diabetes melitus berasal dari data publik Pima Indians Diabetes Database. Dataset tersebut terdiri dari 8 variabel yaitu jumlah kehamilan, kadar gula darah (glukosa), tekanan darah, ketebalan lipatan kulit trisep, kadar insulin, index masa tubuh (IMT), riwayat diabetes melitus dalam keluarga, serta usia. Selain itu, peneliti juga melakukan wawancara dengan seorang dokter untuk menggali informasi lebih dalam terkait penyakit diabetes mellitus.

\subsection{Tahap Pre-processing}

Analisis dataset mengungkapkan bahwa tidak semua variabel memiliki data atribut yang lengkap, dan bahwa kelengkapan atribut memiliki dampak yang signifikan terhadap hasil klasifikasi. Jumlah atribut data tidak lengkap pada masing - masing variable yaitu:

Tabel 1. Data Atribut yang Hilang

\begin{tabular}{|c|l|c|}
\hline No & \multicolumn{1}{|c|}{ Variabel } & Jumlah Data Hilang \\
\hline 1 & Jumlah kehamilan & 110 \\
\hline 2 & Kadar gula darah & 5 \\
\hline 3 & Tekanan darah & 35 \\
\hline 4 & Ketebalan lipatan kulit trisep & 227 \\
\hline 5 & Insulin & 374 \\
\hline 6 & Index Massa Tubuh (IMT) & 11 \\
\hline 7 & Riwayat diabetes dalam keluarga & 0 \\
\hline 8 & Usia & 0 \\
\hline 9 & Hasil prediksi pasien & 0 \\
\hline
\end{tabular}

Lestari, et., al [Penerapan Metode K-Nearest Neighbor Untuk Sistem Pendukung Keputusan Identifikasi Penyakit Diabetes Melitus] 
Untuk mengatasi ketidaklengkapan atribut data dari masing-masing variabel tersebut, maka diberlakukan aturan: 1) Nilai nol dalam variable jumlah kehamilan diasumsikan bahwa pasien belum pernah melahirkan. 2) Nilai nol dalam variabel kadar gula/glukosa, tekanan darah ketebalan lipatan kulit, insulin dan index masa tubuh dihilangkan.

Setelah dilakukan penanganan sesuai dengan kedua aturan yangdiatas, didapat 394 data dari 768 data yang siap diolah ketahap selanjutnya. 394 data tersebut kemudian dibagi menjadi data uji dan data latih dengan perbandingan 1:7 atau 50 data uji dan 344 data latih.

\subsection{Pembuatan Design Sistem}

Pembuatan design sistem dimaksudkan untuk mempermudah pengguna sistem dalam pengoperasikan sistem pendukung keputusan yang dibuat. Design sistem pendukung keputusan ini dibuat dengan menggunakan QtDesigner.

\section{$2.4 \quad$ Penggunaan Metode KNN}

Penggunaan metode KNN dilakukan pada dua kali percobaan, pertama pada sistem yang dibuat serta pada perhitungan dengan menggunakan excel, perhitungan dengan excel dilakukan untuk melihat hasil perhitungan jarak euclidean yang dihasilkan.Langkah-langkah yang dilakukan dalam algoritma KNN yaitu:

1. Menentukan nilai $\mathrm{k}$.

2. Menghitung kuadrat jarak euclid masing-masing objek terhadap data baru. Dengan rumus :

$$
\left(\sum_{k=1}^{m}\left(x_{i k}-x_{j k}\right)^{2}\right)^{1 / 2}
$$

Dimana: $\mathrm{Xik}=$ nilai $\mathrm{X}$ pada data latih

$$
X j k=\text { nilai } X \text { pada data uji }
$$

$\mathrm{m}=$ batas jumlah banyaknya data

3. Mengurutkan objek dari mulai jarak terdekat sampai jarak terjauh

4. Mengumpulkan label class Y (klasifikasi Nearest Neighborhood).

5. Melakukan prediksi berdasarkan label class $Y$ yang paling mayoritas.

\subsubsection{Uji Coba}

Tahapan uji coba dilakukan untuk mengetahui keberhasilan dari sistem yang dibuat. Proses uji coba dilakukan pada data uji dengan menggunakan nilai k paling optimal. Data uji yang digunakan berjumlah 50 data. Pada proses uji coba, tingkat keberhasilan metode diukur berdasarkan tingkat akurasi yang dihasilkan. Accuracy atau akurasi merupakan rasio prediksi benar positif dan benar negatif $(\mathrm{TP}+\mathrm{TN})$ dibandingkan dengan keseluruhan data $(\mathrm{TP}+\mathrm{FP}+$ $\mathrm{TN}+\mathrm{FN})$. Rumus perhitungan akurasi dapat dilihat dibawah ini.

$$
\text { accuracy }=\frac{T P+T N}{T P+F P+T N+F N}
$$

\subsubsection{Penarikan Kesimpulan}

Setelah melakukan seluruh rangkaian proses pada model penelitian yang dilakukan, pada tahapan ini akan dilakukan analisis terhadap hasil dari uji coba dari sistem yang digunakan. Sehingga dapat disimpulkan keunggulan dan kelemahan dari sistem yang dibuat. Tahap akhir ini akan menentukan tindakan yang akan dilakukan peneliti selanjutnya untuk mengembangkan penelitian yang telah dilakukan. 


\section{HASIL DAN PEMBAHASAN}

\subsection{Hasil Pengumpulan Data}

Setelah peneliti melakukan wawancara dan pengumpulan dataset serta pemrosesan data awal maka diperoleh hasil sebagai berikut :

Tabel 2. Hasil Wawancara Dokter

\begin{tabular}{|c|c|c|}
\hline No & Pertanyaan & Jawaban \\
\hline 1 & $\begin{array}{l}\text { Apakah penyakit diabetes } \\
\text { melitus merupakan salah satu } \\
\text { penyakit dengan jumlah pasien } \\
\text { tertinggi? }\end{array}$ & $\begin{array}{l}\text { Ya, jumlah paseien penderita diabetes melitus } \\
\text { dapat dikatakan cukup tinggi, penyakit ini } \\
\text { masuk pada } 10 \text { penyakit terbanyak di } \\
\text { Puskesmas Paiton. }\end{array}$ \\
\hline 2 & $\begin{array}{l}\text { Bagaimana proses identifikasi } \\
\text { penyakit diabetes melitussaat } \\
\text { ini? }\end{array}$ & $\begin{array}{l}\text { Sampai saat ini proses identifikasi terhadap } \\
\text { pasien masih mengandalkan hasil tes dari } \\
\text { laboratorium }\end{array}$ \\
\hline 3 & $\begin{array}{l}\text { Apakah saja faktor faktor yang } \\
\text { menyebabkan seseorang } \\
\text { menderita diabetes melitus? }\end{array}$ & $\begin{array}{l}\text { Banyak faktor yang bisa menyebabkan } \\
\text { seseorang menderita diabetes melitus seperti } \\
\text { hipertensi atau tekanan darah tinggi, kadar } \\
\text { gula berlebih, obesitas yang ditandai dengan } \\
\text { index massa tubuh } \geq 25 \mathrm{~kg} / \mathrm{m} 2 \text {, riwayat } \\
\text { penyakit diabetes melitus dalam keluarga, usia } \\
\geq 45 \text { tahun, jumlah kehamilan (terutama } \\
\text { kehamilan bermasalah, seperti bayi lahir } \\
\text { meninggal serta bayi lahir besar), ketebalan } \\
\text { lipatan kulit trisep, jumlah kadar insulin } \\
\text { dalam tubuh, kurangnya aktivitas fisik serta } \\
\text { pola hidup dan diet tidak sehat. }\end{array}$ \\
\hline
\end{tabular}

Tabel 3. Data Latih

\begin{tabular}{|c|c|c|c|c|c|c|c|c|c|}
\hline No & Pregnancies & Glucose & BloodPressure & SkinThickness & Insulin & BMl & Pedigreel & Age & Outcome \\
\hline 1 & 0 & 137 & 40 & 35 & 168 & 43.1 & 2.288 & 33 & 1 \\
\hline 2 & 3 & 78 & 50 & 32 & 88 & 31 & 0.248 & 26 & 1 \\
\hline 3 & 2 & 197 & 70 & 45 & 543 & 30.5 & 0.158 & 53 & 1 \\
\hline 4 & 1 & 189 & 60 & 23 & 846 & 30.1 & 0.398 & 59 & 1 \\
\hline 5 & 5 & 166 & 72 & 19 & 175 & 25.8 & 0.587 & 51 & 1 \\
\hline 6 & 0 & 118 & 84 & 47 & 230 & 45.8 & 0.551 & 31 & 1 \\
\hline 7 & 1 & 103 & 30 & 38 & 83 & 43.3 & 0.183 & 33 & 0 \\
\hline 8 & 1 & 115 & 70 & 30 & 96 & 34.6 & 0.529 & 32 & 1 \\
\hline$\ldots$ & $\ldots$ & $\ldots$ & $\ldots$ & $\ldots$ & $\ldots$ & $\ldots$ & $\ldots$ & $\ldots$ & $\ldots$ \\
\hline 344 & 1 & 101 & 50 & 15 & 36 & 24.2 & 0.526 & 26 & 0 \\
\hline
\end{tabular}


Jatisi

ISSN 2407-4322

Vol. 8, No. 4, Desember 2021, Hal. 2071-2082

E- ISSN 2503-2933

Tabel 4. Data Uji

\begin{tabular}{|c|c|c|c|c|c|c|c|c|c|}
\hline No & Pregnancies & Glucose & BloodPressure & SkinThickness & Insulin & BMl & Pedigreel & Age & Outcome \\
\hline 1 & 1 & 99 & 72 & 30 & 18 & 38.6 & 0.412 & 21 & 0 \\
\hline 2 & 6 & 92 & 62 & 32 & 126 & 32 & 0.085 & 46 & 0 \\
\hline 3 & 4 & 154 & 72 & 29 & 126 & 31.3 & 0.338 & 37 & 0 \\
\hline 4 & 1 & 109 & 60 & 8 & 182 & 25.4 & 0.947 & 21 & 0 \\
\hline 5 & 3 & 111 & 58 & 31 & 44 & 29.5 & 0.43 & 22 & 0 \\
\hline 6 & 2 & 98 & 60 & 17 & 120 & 34.7 & 0.198 & 22 & 0 \\
\hline 7 & 1 & 143 & 86 & 30 & 330 & 30.1 & 0.892 & 23 & 0 \\
\hline 8 & 1 & 119 & 44 & 47 & 63 & 35.5 & 0.28 & 25 & 0 \\
\hline$\ldots$ & $\ldots$ & $\ldots$ & $\ldots$ & $\ldots$ & $\ldots$ & $\ldots$ & $\ldots$ & $\ldots$ & $\ldots$ \\
\hline 50 & 7 & 97 & 76 & 32 & 91 & 40.9 & 0.871 & 32 & 1 \\
\hline
\end{tabular}

\subsection{Hasil Pembuatan Design Sistem}

Hasil pembuatan design sistem tersebut kemudian disimpan dengan nama diabetes.ui.

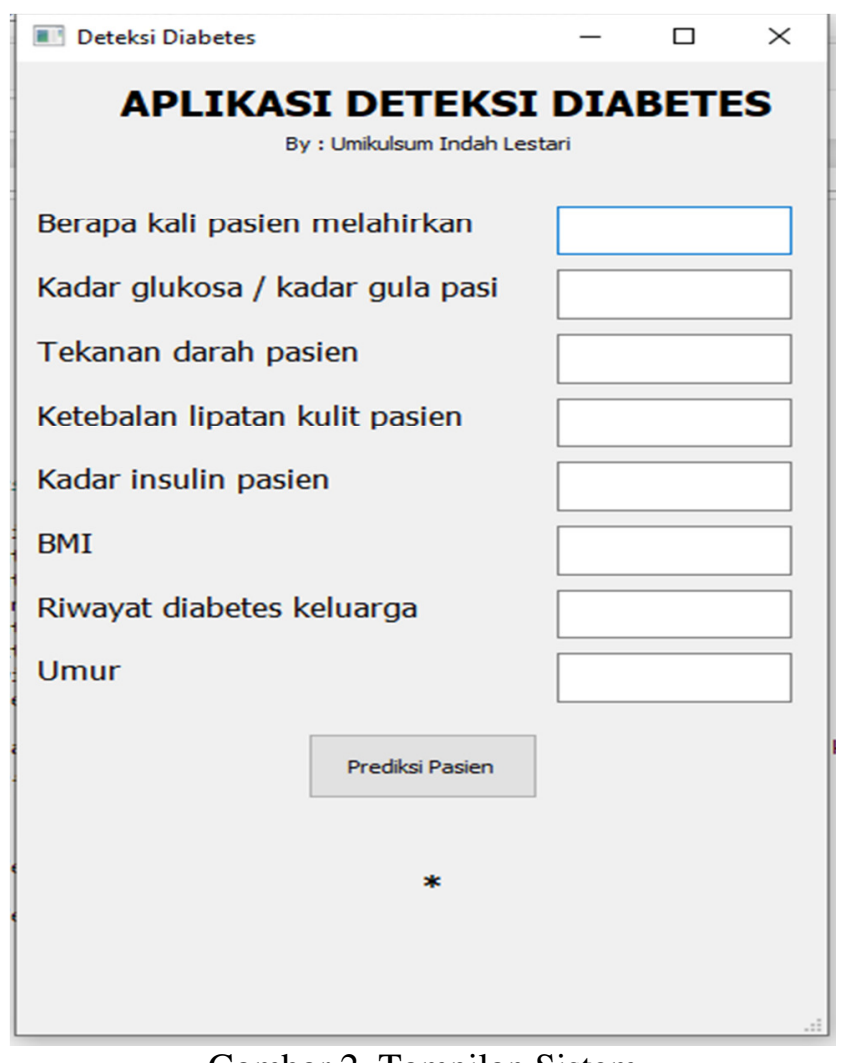

Gambar 2. Tampilan Sistem

\subsection{Hasil Penggunaan Metode KNN}

\subsubsection{Penggunaan Metode KNN Pada Sistem}

1. Mencari Nilai k Terbaik

Langkah pertama yang perlu dilakukan dalam membuat sistem pendukung keputusan adalah mencari nikai $\mathrm{k}$ terbaik dengan tingkat akurasi tertingi 


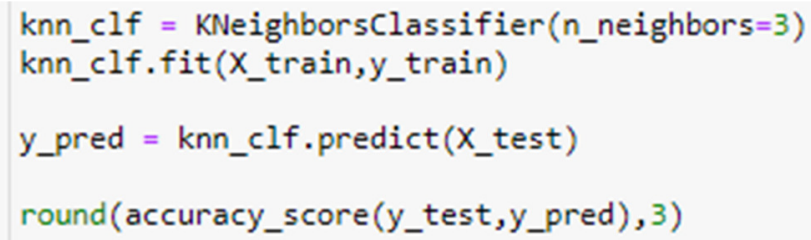

Gambar 3. Proses Mencari Nilai k Paling Optimal

Pada tahap ini dilakukan pengujian tehadap angka angka ganjil dalam rentan 1-30, sehingga menghasilkan tingkat akurasi sebagai berikut:

\section{Tabel 5. Hasil Akurasi Nilai K}

\begin{tabular}{|c|c|}
\hline $\mathrm{K}$ & Akurasi \\
\hline 1 & $80 \%$ \\
\hline 3 & $82 \%$ \\
\hline 5 & $90 \%$ \\
\hline 7 & $88 \%$ \\
\hline 9 & $90 \%$ \\
\hline
\end{tabular}

\begin{tabular}{|c|c|}
\hline $\mathrm{K}$ & Akurasi \\
\hline 11 & $90 \%$ \\
\hline 13 & $94 \%$ \\
\hline 15 & $92 \%$ \\
\hline 17 & $94 \%$ \\
\hline 19 & $94 \%$ \\
\hline
\end{tabular}

\begin{tabular}{|c|c|}
\hline K & Akurasi \\
\hline 21 & $94 \%$ \\
\hline 23 & $96 \%$ \\
\hline 25 & $92 \%$ \\
\hline 27 & $92 \%$ \\
\hline 29 & $92 \%$ \\
\hline
\end{tabular}

Berdasarkan uji hasil akurasi tersebut, maka didapatkan nilai k terbaik adalah 23 dengan tingkat akurasi mencapai $96 \%$

\section{Pembuatan Sistem}

Pada tahap ini hasil pembuatan design serta model akurasi paling optimal yang telah dibuat sebelumnya akan disatukan sehingga nantinya akan menghasilkan suatu sistem pendukung keputusan yang siap digunakan kapan saja.

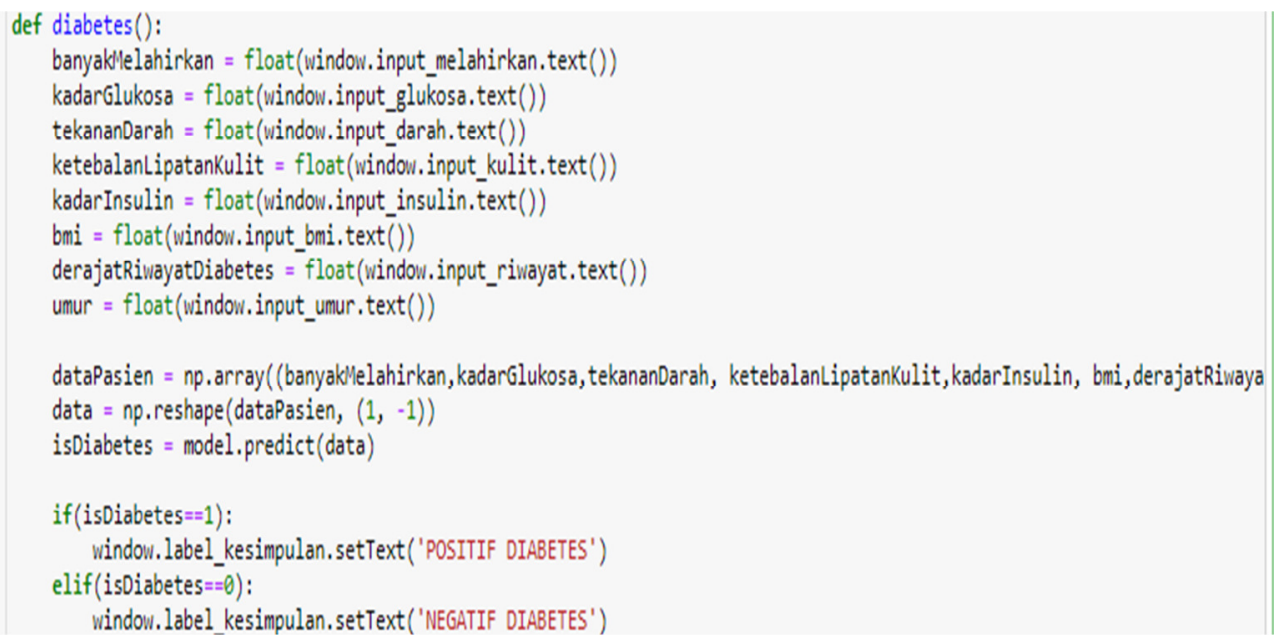

\section{Gambar 4. Proses Prediksi Pada Sistem}

Pada tahap ini dilakukan prediksi data baru terhadap data latih yang ada, kemudia hasil dari prediksi tersebut disimpan dalam satu variable yaitu isDiabates. Apabila hasil prediksi dari isDiabetes menghasilkan angka 1 maka sistem akan menampilkannya sebagai positif diabetes, 
sedangkan jika hasil prediksi menghasilkan angka 0 , maka sistem akan menampilkannya sebagai negatif diabetes.

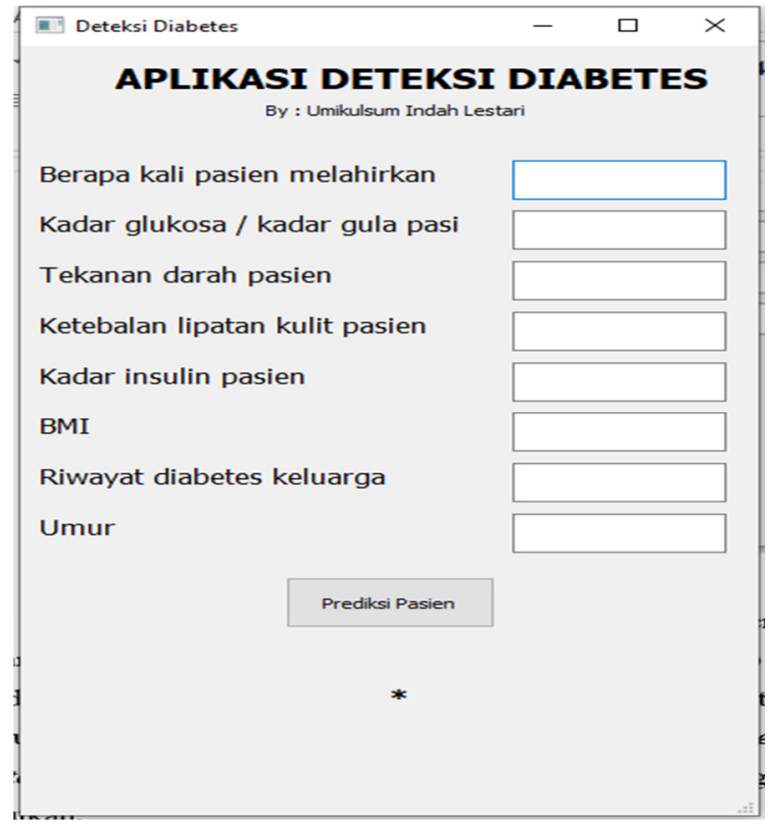

Gambar 5. Hasil Tampilan Awal Sistem

Berdasarkan Gambar diatas dapat dilihat bahwa terdapat 8 variabel inputan yang perlu diisi sebelum melakukan prediksi terhadap pasien, tampilan awal dari hasil prediksi hanya berupa tanda bintang $(*)$ saja, tanda bintang $(*)$ tersebut nantinya akan berubah sesuai menjadi positif diabetes atau negatif diabetes sesuai dengan prediksi sistem terhadap pasien yang datanya sedang diinputkan.Untuk itu dilakukan pengujian awal dengan mengambil dua data uji yaitu satu data positif dan satu data negatif.

Data uji:

\begin{tabular}{|c|c|c|c|c|c|c|c|c|}
\hline Pregnancies & Glucose & Blood Pressure & Skin Thickness & Insulin & BMI & Diabetes Pedigree Function & Age & Outcome \\
\hline 1 & 99 & 72 & 30 & 18 & 38.6 & 0.412 & 21 & 0 \\
\hline
\end{tabular}

Prediksi yang dihasilkan sistem terhadap data uji tersebut dapat dilihat dibawah ini: 


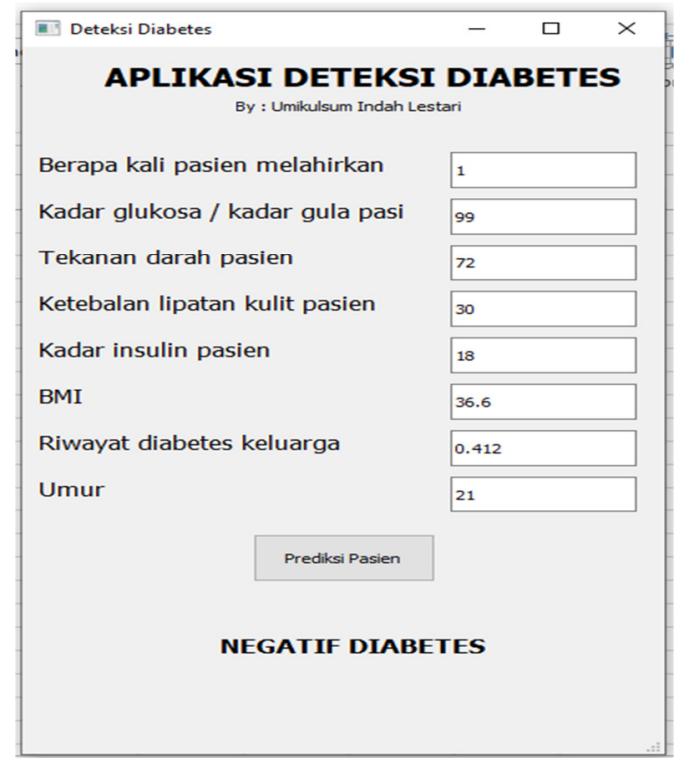

Gambar 6. Hasil Prediksi Sistem

\subsubsection{Perhitungan Metode KNN}

Berdasarkan prediksi yang telah dilakukan pada Gambar 6 dapat dilihat bahwa sistem hanya menampilkan hasil akhir atau hasil prediksinya saja tanpa proses perhitungan algoritma jarak Euclidean. Dengan nilai k =23. Sehingga menghasilkan:

Tabel 6. Urutan Jarak Euclidean

\begin{tabular}{|c|c|c|c|c|c|c|c|c|c|c|}
\hline Pregnancies & Glucose & Blood Pressure & Skin Thickness & Insulin & $\mathrm{BMI}$ & Diabetes Pedigree Function & Age & Outcome & Jarak & Urutan ke \\
\hline 1 & 87 & 78 & 27 & 32 & 34.6 & 0.101 & 22 & 0 & 20.05234951 & 1 \\
\hline 2 & 88 & 58 & 26 & 16 & 28.4 & 0.766 & 22 & 0 & 21.05149201 & 2 \\
\hline 3 & 83 & 58 & 31 & 18 & 34.3 & 0.336 & 25 & 0 & 22.16970401 & 3 \\
\hline 0 & 95 & 85 & 25 & 36 & 37.4 & 0.247 & 24 & 1 & 23.35523978 & 4 \\
\hline 1 & 89 & 76 & 34 & 37 & 31.2 & 0.192 & 23 & 0 & 23.49060238 & 5 \\
\hline 5 & 88 & 66 & 21 & 23 & 24.4 & 0.342 & 30 & 0 & 23.6990485 & 6 \\
\hline 1 & 88 & 62 & 24 & 44 & 29.9 & 0.422 & 23 & 0 & 31.82279215 & 7 \\
\hline 1 & 79 & 80 & 25 & 37 & 25.4 & 0.583 & 22 & 0 & 32.01982575 & 8 \\
\hline 1 & 81 & 72 & 18 & 40 & 26.6 & 0.283 & 24 & 0 & 33.24179058 & 9 \\
\hline 0 & 100 & 70 & 26 & 50 & 30.8 & 0.597 & 21 & 0 & 33.26971934 & 10 \\
\hline 1 & 95 & 66 & 13 & 38 & 19.6 & 0.334 & 25 & 0 & 33.43659797 & 11 \\
\hline 0 & 78 & 88 & 29 & 40 & 36.9 & 0.434 & 21 & 0 & 34.43676065 & 12 \\
\hline 2 & 99 & 70 & 16 & 44 & 20.4 & 0.235 & 27 & 0 & 35.27423038 & 13 \\
\hline 5 & 126 & 78 & 27 & 22 & 29.6 & 0.439 & 40 & 0 & 35.32705378 & 14 \\
\hline 1 & 90 & 62 & 12 & 43 & 27.2 & 0.58 & 24 & 0 & 35.62286097 & 15 \\
\hline 1 & 101 & 50 & 15 & 36 & 24.2 & 0.526 & 26 & 0 & 35.6282612 & 16 \\
\hline 2 & 83 & 66 & 23 & 50 & 32.2 & 0.497 & 22 & 0 & 37.52288935 & 17 \\
\hline 3 & 74 & 68 & 28 & 45 & 29.7 & 0.293 & 23 & 0 & 38.22596187 & 18 \\
\hline 5 & 77 & 82 & 41 & 42 & 35.8 & 0.156 & 35 & 0 & 38.74152212 & 19 \\
\hline 2 & 88 & 74 & 19 & 53 & 29 & 0.229 & 22 & 0 & 39.56252632 & 20 \\
\hline 4 & 99 & 76 & 15 & 51 & 23.2 & 0.223 & 21 & 0 & 39.70133148 & 21 \\
\hline 4 & 85 & 58 & 22 & 49 & 27.8 & 0.306 & 28 & 0 & 39.89550396 & 22 \\
\hline 2 & 96 & 68 & 13 & 49 & 21.1 & 0.647 & 26 & 0 & 40.09121132 & 23 \\
\hline$\ldots$ & $\ldots$ & $\ldots$ & $\ldots$ & $\ldots$ & $\ldots$ & $\ldots$ & $\ldots$ & $\ldots$ & $\ldots$ & $\ldots$ \\
\hline 1 & 189 & 60 & 23 & 846 & 30.1 & 0.398 & 59 & 1 & 833.9024225 & 344 \\
\hline
\end{tabular}

Berdasarkan hasil tersebut dapat kita hitung jumlah prediksi positif (outcome 1) sebanyak 1 dan prediksi negatif (outcome 0) sebanyak 22 data. jadi dapat disimpulkan bahwa data yang baru saja diinputkan adalah negatif diabetes. 


\subsection{Hasil Uji Coba}

Proses uji coba dilakukan pada data uji dengan menggunakan nilai k paling optimal. Data uji yang digunakan berjumlah 50 data. 50 data tersebut kemudian akan diberikan variabel nilainya untuk menghitung tingkat akurasi dari sistem yang dibuat.

Tabel 7. Variabel Nilai

\begin{tabular}{|c|c|c|c|c|c|c|c|c|c|c|}
\hline Pregnancies & Glucose & Blood Pressure & Skin Thickness & Insulin & BMl & Diabetes Pedigree Function & Age & Outcome & Keterangan & Variabel Nilai \\
\hline 1 & 99 & 72 & 30 & 18 & 38.6 & 0.412 & 21 & 0 & Benar & TN \\
\hline 6 & 92 & 62 & 32 & 126 & 32 & 0.085 & 46 & 0 & Benar & TN \\
\hline 4 & 154 & 72 & 29 & 126 & 31.3 & 0.338 & 37 & 0 & Salah & FN \\
\hline 1 & 109 & 60 & 8 & 182 & 25.4 & 0.947 & 21 & 0 & Benar & TN \\
\hline 3 & 111 & 58 & 31 & 44 & 29.5 & 0.43 & 22 & 0 & Benar & TN \\
\hline 2 & 98 & 60 & 17 & 120 & 34.7 & 0.198 & 22 & 0 & Benar & TN \\
\hline 1 & 143 & 86 & 30 & 330 & 30.1 & 0.892 & 23 & 0 & Benar & TN \\
\hline 1 & 119 & 44 & 47 & 63 & 35.5 & 0.28 & 25 & 0 & Benar & TN \\
\hline 6 & 108 & 44 & 20 & 130 & 24 & 0.813 & 35 & 0 & Benar & TN \\
\hline 8 & 124 & 76 & 24 & 600 & 28.7 & 0.687 & 52 & 1 & Benar & TP \\
\hline 3 & 176 & 86 & 27 & 156 & 33.3 & 1.154 & 52 & 1 & Benar & TP \\
\hline 2 & 112 & 78 & 50 & 140 & 39.4 & 0.175 & 24 & 0 & Benar & TN \\
\hline 2 & 82 & 52 & 22 & 115 & 28.5 & 1.699 & 25 & 0 & Benar & TN \\
\hline 6 & 123 & 72 & 45 & 230 & 33.6 & 0.733 & 34 & 0 & Benar & TN \\
\hline 0 & 188 & 82 & 14 & 185 & 32 & 0.682 & 22 & 1 & Benar & TP \\
\hline
\end{tabular}

\begin{tabular}{|c|c|c|c|c|c|c|c|c|c|c|}
\hline 1 & 89 & 24 & 19 & 25 & 27.8 & 0.559 & 21 & 0 & Benar & $\mathrm{TN}$ \\
\hline 1 & 109 & 38 & 18 & 120 & 23.1 & 0.407 & 26 & 0 & Benar & TN \\
\hline 1 & 109 & 58 & 18 & 116 & 28.5 & 0.219 & 22 & 0 & Benar & $\mathrm{TN}$ \\
\hline 1 & 181 & 78 & 42 & 293 & 40 & 1.258 & 22 & 1 & Benar & TP \\
\hline 1 & 92 & 62 & 25 & 41 & 19.5 & 0.482 & 25 & 0 & Benar & $\mathrm{TN}$ \\
\hline 0 & 152 & 82 & 39 & 272 & 41.5 & 0.27 & 27 & 0 & Benar & TN \\
\hline 1 & 111 & 62 & 13 & 182 & 24 & 0.138 & 23 & 0 & Benar & TN \\
\hline 3 & 106 & 54 & 21 & 158 & 30.9 & 0.292 & 24 & 0 & Benar & TN \\
\hline 7 & 168 & 88 & 42 & 321 & 38.2 & 0.787 & 40 & 1 & Benar & TP \\
\hline 8 & 196 & 76 & 29 & 280 & 37.5 & 0.605 & 57 & 1 & Benar & $\mathrm{TP}$ \\
\hline 2 & 68 & 62 & 13 & 15 & 20.1 & 0.257 & 23 & 0 & Benar & TN \\
\hline 2 & 112 & 86 & 42 & 160 & 38.4 & 0.246 & 28 & 0 & Benar & TN \\
\hline 0 & 94 & 70 & 27 & 115 & 43.5 & 0.347 & 21 & 0 & Benar & $\mathrm{TN}$ \\
\hline 4 & 90 & 88 & 47 & 54 & 37.7 & 0.362 & 29 & 0 & Benar & TN \\
\hline 0 & 102 & 78 & 40 & 90 & 34.5 & 0.238 & 24 & 0 & Benar & TN \\
\hline 1 & 128 & 82 & 17 & 183 & 27.5 & 0.115 & 22 & 0 & Benar & TN \\
\hline 2 & 94 & 76 & 18 & 66 & 31.6 & 0.649 & 23 & 0 & Benar & TN \\
\hline 2 & 106 & 56 & 27 & 165 & 29 & 0.426 & 22 & 0 & Benar & $\mathrm{TN}$ \\
\hline 1 & 100 & 74 & 12 & 46 & 19.5 & 0.149 & 28 & 0 & Benar & TN \\
\hline 0 & 102 & 86 & 17 & 105 & 29.3 & 0.695 & 27 & 0 & Benar & TN \\
\hline 3 & 103 & 72 & 30 & 152 & 27.6 & 0.73 & 27 & 0 & Benar & TN \\
\hline 0 & 126 & 86 & 27 & 120 & 27.4 & 0.515 & 21 & 0 & Benar & TN \\
\hline 1 & 167 & 74 & 17 & 144 & 23.4 & 0.447 & 33 & 1 & Benar & TP \\
\hline 0 & 179 & 50 & 36 & 159 & 37.8 & 0.455 & 22 & 1 & Benar & TP \\
\hline 2 & 174 & 88 & 37 & 120 & 44.5 & 0.646 & 24 & 1 & Benar & TP \\
\hline 1 & 91 & 54 & 25 & 100 & 25.2 & 0.234 & 23 & 0 & Benar & $\mathrm{TN}$ \\
\hline 1 & 117 & 60 & 23 & 106 & 33.8 & 0.466 & 27 & 0 & Benar & $\mathrm{TN}$ \\
\hline 5 & 123 & 74 & 40 & 77 & 34.1 & 0.269 & 28 & 0 & Benar & TN \\
\hline 1 & 106 & 70 & 28 & 135 & 34.2 & 0.142 & 22 & 0 & Benar & TN \\
\hline 2 & 155 & 52 & 27 & 540 & 38.7 & 0.24 & 25 & 1 & Benar & TP \\
\hline 2 & 101 & 58 & 35 & 90 & 21.8 & 0.155 & 22 & 0 & Benar & $\mathrm{TN}$ \\
\hline 1 & 120 & 80 & 48 & 200 & 38.9 & 1.162 & 41 & 0 & Benar & $\mathrm{TN}$ \\
\hline 3 & 187 & 70 & 22 & 200 & 36.4 & 0.408 & 36 & 1 & Benar & TP \\
\hline 8 & 167 & 106 & 46 & 231 & 37.6 & 0.165 & 43 & 1 & Benar & TP \\
\hline 7 & 97 & 76 & 32 & 91 & 40.9 & 0.871 & 32 & 1 & Salah & FP \\
\hline
\end{tabular}


Berdasarkan tabel variabel nilai diatas maka didapat :

$\begin{array}{ll}\text { True Positive (TP) atau Benar Positif } & =12 \text { data } \\ \text { True Negative (TN) atau Benar Negatif } & =36 \text { data } \\ \text { False Positive (FP) atau Salah Positif } & =1 \text { data } \\ \text { False Negative (FN) atau Salah Negatif } & =1 \text { data }\end{array}$

Sehingga kemudian dapat dihitung tingkat akurasi dari sistem yang dibuat dengan rumus akurasi $:$ accuracy $=\frac{T P+T N}{T P+F P+T N+F N}=\frac{12+36}{12+1+36+1}=0.96$

\section{KESIMPULAN}

Berdasarkan implementasi dan pengujian, dengan nilai $\mathrm{k}=23$ didapatkan tingkat akurasi sebesar 0.96 atau 96\%, tingkat akurasi tersebut dinilai cukup tinggi sehingga penelitian ini dinilai telah berhasil menerapkan metode KNN untuk sistem pendukung keputusan identifikasi penyakit diabetes melitus sejak dini.

\section{SARAN}

Pada penelitian selanjutnya diharapkan dapat mengidentifikasi penyakit diabetes dengan pengembangan metode yang lain dan terbaru dengan tingkat akurasi yang lebih tinggi, salah satunya adalah metode C 4.5 dengan menggunakan cangkupan variable yang lebih luas lagi seperti gejala gejala yang dialami penderita penyakit diabetes, beberapa diantaranya adalah gejala sering haus dan sering kencing dimalam hari. Aplikasi ini juga diharapkan dapat dikembangkan kedalam versi mobile atau android yang dapat turut serta menampilkan hasil perhitungan jarak euclidean.

\section{UCAPAN TERIMA KASIH}

Terimakasih penulis ucapkan kepada Dokter Nina dan Dokter Nindri selaku Kepala serta Dokter di Puskesmas Paiton yang telah sudi meluangkan waktunya untuk wawancara.

\section{DAFTAR PUSTAKA}

[1] International Diabetes Federation. 2015, IDF Diabetes Atlas, Seventh Edition 2015. [online], http://www.idf.org/ idf-diabetes-atlas-seventh-edition (2015).

[2] American Diabetes Association. 2018, American Diabetes Association Standards of Medical Care In Diabetes, ADA, USA.

[3] American Diabetes Association. 2017, Standards of Medical Care in Diabetes 2017, ADA. USA.

[4] American Diabetes Association. 2020, Standards of Medical Care in Diabetes, ADA. USA. 
[5] Santoso, R. R., Megasari, R., \& Hambali, Y. A. 2020, Implementasi Metode Machine Learning Menggunakan Algoritma Evolving Artificial Neural Network pada Kasus Prediksi Diagnosis Diabetes, JATIKOM: Jurnal Aplikasi dan Teori Ilmu Komputer, 8597.

[6] Santoso, H. F., Darwiyanto, E., \& Wisesty, U. N. 2016, Analisis dan Implementasi Metode Certainty Factor pada Sistem Pendukung Pengambilan Keputusan untuk Penyakit Diabetes Melitus. e-Proceeding of Engineering, 5191.

[7] Ramadhani, R. A., \& Niswatin, R. K. 2018, Sistem Diagnosa Diabetes Menggunakan Metode KNN. Jurnal Sains dan Informatika, 98-104.

[8] Noviandi. 2018. Implementasi Algoritma Decision Tree C4.5 Untuk Prediksi Penyakit Diabetes. Jurnal INOHIM, Volume 6 Nomor 1, 1-5.

[9] Sihotang, H. T., \& Siboro, M. S. 2016, Aplikasi Sistem Pendukung Keputusan Penentuan Siswabermasalah Menggunakan Metode SAW pada Sekolah SMP Swasta Mulia Pratama Medan, JIPN (Journal of Informatics Pelita Nusantara), 1-6.

[10] Baharuddin, M. M., Hasanuddin , T., \& Azis, H. 2019, Analisis Performa Metode KNearest Neighbor Untuk Identifikasi Jenis Kaca, ILKOM Jurnal Ilmiah Volume 11 Nomor 3, 269-274. 